\title{
eDNA Increases the Detectability of Ranavirus Infection in an Alpine Amphibian Population
}

\author{
Claude Miaud ${ }^{1, *(1)}$, Véronique Arnal ${ }^{1}$, Marie Poulain ${ }^{1}$, Alice Valentini ${ }^{2}$ and Tony Dejean ${ }^{2}$ \\ 1 CEFE, EPHE-PSL, CNRS, Univ. Montpellier, Univ Paul Valéry Montpellier 3, IRD, Biogeography and \\ Vertebrate Ecology, 1919 route de Mende, 34293 Montpellier, France; veronique.arnal@cefe.cnrs.fr (V.A.); \\ marie.poulain@cefe.cnrs.fr (M.P.) \\ 2 SPYGEN, 17 Rue du Lac Saint-André, 73370 Le Bourget-du-Lac, France; alice.valentini@spygen.com (A.V.); \\ tony.dejean@spygen.com (T.D.) \\ * Correspondence: claude.miaud@cefe.cnrs.fr; Tel.: +33-(0)4-67-61-33-43
}

Received: 15 March 2019; Accepted: 4 June 2019; Published: 6 June 2019

check for updates

\begin{abstract}
The early detection and identification of pathogenic microorganisms is essential in order to deploy appropriate mitigation measures. Viruses in the Iridoviridae family, such as those in the Ranavirus genus, can infect amphibian species without resulting in mortality or clinical signs, and they can also infect other hosts than amphibian species. Diagnostic techniques allowing the detection of the pathogen outside the period of host die-off would thus be of particular use. In this study, we tested a method using environmental DNA (eDNA) on a population of common frogs (Rana temporaria) known to be affected by a Ranavirus in the southern Alps in France. In six sampling sessions between June and September (the species' activity period), we collected tissue samples from dead and live frogs (adults and tadpoles), as well as insects (aquatic and terrestrial), sediment, and water. At the beginning of the breeding season in June, one adult was found dead; at the end of July, a mass mortality of tadpoles was observed. The viral DNA was detected in both adults and tadpoles (dead or alive) and in water samples, but it was not detected in insects or sediment. In live frog specimens, the virus was detected from June to September and in water samples from August to September. Dead tadpoles that tested positive for Ranavirus were observed only on one date (at the end of July). Our results indicate that eDNA can be an effective alternative to tissue/specimen sampling and can detect Ranavirus presence outside die-offs. Another advantage is that the collection of water samples can be performed by most field technicians. This study confirms that the use of eDNA can increase the performance and accuracy of wildlife health status monitoring and thus contribute to more effective surveillance programs.
\end{abstract}

Keywords: eDNA; Ranavirus; Common frog; Rana temporaria; early detection; virus surveillance

\section{Introduction}

Amphibians are often considered ecosystem health indicators ("the canaries in the coal mine", [1]) due to their permeable skin, their sensitivity to environmental disturbance, and their often biphasic (requiring water and land) life cycle (e.g., [2]). Over $40 \%$ of the more than 7000 species that have been evaluated are classified as threatened today, and the main cause of the disappearance or decline of amphibian populations is the degradation and destruction of their habitats [3]. Emerging infectious diseases (EIDs) are also causing drastic amphibian declines worldwide [4-6], and the chytridiomycosis panzootic has been involved in the decline of at least 501 amphibian species over the past half-century, including 90 presumed extinctions [7]. Ranaviruses (family Iridoviridae)—double-stranded DNA viruses that infect fish, reptiles, and amphibians [8] —are considered the second most common infectious cause of mortality in amphibians $[9,10]$. These viruses have caused amphibian die-offs on 
five continents [11]. The common midwife toad virus (CMTV) [12] is a Ranavirus that has been causing amphibian die-offs since 2005 in Spain [10]. Since then, CMTV-related mortality has been recorded in other European countries, affecting several amphibian species in both Anura and Caudata [13,14].

The rapid and accurate identification of pathogenic microorganisms is essential for the early detection of infection and the deployment of appropriate mitigation measures [15]. Several field studies have reported Ranavirus-infected amphibians that do not present clinical signs or histological changes (e.g., [16]). The use of molecular techniques to identify microbial pathogens (e.g., see reviews in [17] for fungus and [18] for viruses) has considerably improved detection possibilities. Molecular tools applied to environmental samples are now widely used to identify infectious agents [19] and are particularly promising for the early detection of aquatic pathogens that can be introduced by non-native species (e.g., [20]). In the last decade, the DNA detection of pathogens in environmental samples (e.g., in water) has been performed successfully to identify several metazoan parasites, fungi (Chytrid and Oomycota), and Ranaviruses [21-28]. By comparing water samples and the Ranavirus infection status of wood frog tadpoles (Lithobates sylvaticus) in several ponds in north-eastern Connecticut in the United States, Hall et al. (2016) [24] demonstrated a strong relationship between the viral load in environmental DNA (eDNA) and larval tissues, indicating the effectiveness of eDNA-based Ranavirus detection in the field.

In Europe, Ranavirus infections and die-offs have been described in four amphibian families and ten species [8,13]. One of these species is the common frog (Rana temporaria), which is experiencing population die-offs in alpine lakes [13]. This study had two key aims: (1) To describe the infection status of different potential hosts of Ranavirus (common frog adults, tadpoles, and insects) and ecosystem compartments (sediment and water) in an alpine lake during the activity period (summer), both prior to and after an observed die-off; and (2) to use the eDNA method to detect Ranavirus during this infection event. We also compared previous studies using eDNA to detect Chytrids and Ranavirus to provide some recommendations for a more effective implementation of water sampling in monitoring programs.

\section{Materials and Methods}

\subsection{Study Area}

The study was conducted in Mercantour National Park in the south-eastern Alps in France. The sampled area consisted of several small lakes and a pond. Balaour pond (44.1082 N, 7.3742 E) is $25 \times 20 \mathrm{~m}$, and $2355 \mathrm{~m}$ a.s.l. It lies at a distance approximately $100 \mathrm{~m}$ from the closest lake. The maximum depth is $1.5 \mathrm{~m}$, and the bottom is granitic rock, partly covered by a shallow ( $\max 0.10 \mathrm{~m}$ ) sedimentary layer of mud. There is no macrophytic vegetation.

The common frog R. temporaria uses these kinds of water bodies for breeding and hibernation in this alpine region [29]. In the study area, the common frog is the only amphibian species present, and it breeds only in Balaour pond (no breeding in the neighboring lakes). Many lakes are stocked with brown trout (Salmo trutta), and the common minnow (Phoxinus phoxinus), which is used as bait, has also been introduced in the lakes. However, there are no trout or minnows in the studied pond.

\subsection{Water Temperature}

The water temperature during the study was recorded using two data loggers (model iBCod 21G, Maxim/Dallas Semiconductor Inc., San Jose, CA, USA, accuracy $+/-1^{\circ} \mathrm{C}$ ). These were attached to a PVC tube (50 mm diameter; $40 \mathrm{~cm}$ in length) with one end glued to a $20 \times 20 \mathrm{~cm}$ polystyrene float. One logger was positioned just below the float, and the other was positioned $25 \mathrm{~cm}$ from the first logger. They were programmed to record the temperature every two hours. The device was set in the field at 14:00 on the first day of the survey (11 June 2016) and remained there until 10:00 on the last day (19 September 2016). To do this, a $2 \mathrm{~m}$ high metallic pole was staked into the ground in the middle of Balaour pond (depth about $1 \mathrm{~m}$ ). The PVC tube was then fitted to the pole with the float at the top. The data loggers were at a depth of about 5 and $30 \mathrm{~cm}$, respectively. The PVC tube and 
float were designed to follow changes in water level so the data loggers recorded temperatures at a constant depth.

\subsection{Amphibian Sampling}

Sampling was carried out at Balaour pond on six dates between June and September in 2016 (Table 1), covering the developmental period of embryos and tadpoles in this region and at this altitude.

Table 1. Sampling at Balaour pond in 2016.

\begin{tabular}{lllllll}
\hline \multirow{2}{*}{ Samples } & \multicolumn{5}{c}{ Date } \\
\cline { 2 - 6 } & 10-11 June & 23-24 June & 08 July & 27 July & 15-16 August & 19 September \\
\hline Tadpole alive & $5(9-11)^{1}$ & $5(24-25)$ & $5(30)$ & $5(35-39)$ & $5(39-41)$ & $5(43-45)$ \\
Tadpole dead $^{\text {Adult alive }}{ }^{2}$ & - & - & - & $10(35-39)$ & - & 5 \\
Adult dead $^{\text {Terrestrial insects }}{ }^{3}$ & 1 & 5 & 5 & 0 & 1 & - \\
Aquatic insects $^{4}$ & 1 & - & - & - & - & 1 \\
Sediment $^{5}$ & 1 & 1 & 1 & 1 & 1 & 1 \\
Water $^{6}$ & 1 & 1 & 1 & 1 & 1 & 1 \\
\hline
\end{tabular}

${ }^{1}$ Stage of development (based on Gosner stages [30]); ${ }^{2}$ the distal phalange of the second forelimb toe was collected from adults caught in water; ${ }^{3}$ one sample per date, consisting of all flying insects caught with three yellow plates placed around the pond and then pooled together; ${ }^{4}$ one sample per date, consisting of all aquatic insects caught by dip-netting in the pond and then pooled together; ${ }^{5}$ one sample of sediment per date, consisting of 20 subsamples collected around the pond and then pooled together; ${ }^{6}$ one sample of water per date, consisting of 20 subsamples collected around the pond, filtered and pooled together (see M\&M for more details).

The pond was visually scanned to detect tadpoles and adults resting on the bottom. Live tadpoles were caught by a dip-net (mesh $1 \mathrm{~mm}$ ). They were stored in individual plastic bottles $(1.5 \mathrm{~mL})$ filled with 95\% ethanol. Dead tadpoles were collected and stored similarly. Live adults were caught by a dip-net (5 mm mesh), and the distal phalange of the second forelimb toe was collected and stored individually in a snap-cap tube $(1.5 \mathrm{~mL})$ filled with $95 \%$ ethanol. Disposable gloves were used and changed between each sampling, and the material (scissors and pliers) was soaked in ethanol and passed through a flame between each sample collection. The dead adults were collected with the dip-net and stored in a plastic bottle $(300 \mathrm{~mL})$ filled with $95 \%$ ethanol. Table 1 shows the sample size and developmental stages [30] of the tadpoles and adults collected. The toe clipping allowed us to check that unique adult specimens were sampled during the study period.

\subsection{Insect Sampling}

Both terrestrial and aquatic insects were collected in the six sampling sessions (Table 1). Terrestrial insects were collected using three yellow plastic plates placed on the ground about $10 \mathrm{~m}$ from the edge of the pond. These plates were filled with water and one drop of domestic detergent. After one hour of sampling, the flying insects found dead in the liquid were collected and stored in a $15 \mathrm{~mL}$ plastic bottle filled with 95\% ethanol. Aquatic insects were caught by dip-netting (1 mm mesh), mostly in the shallow area of the pond (less than $0.60 \mathrm{~m}$ deep). To limit contamination with the surrounding water, each specimen was removed with needle-nose pliers and washed with distilled water. The aquatic insects collected on the same date were stored in the same $15 \mathrm{~mL}$ plastic bottle filled with $95 \%$ ethanol.

\subsection{Water Sampling}

The field survey method was modified from that used in [31]. Using a sterile water-sample dipper, a $100 \mathrm{~mL}$ water sample was collected at 20 locations equally spaced around the edge of Balaour pond, resulting in a pooled sample of approximately $2 \mathrm{~L}$ contained in a sterile self-supporting plastic bag. Samples were collected from the top $0.10 \mathrm{~m}$ of the water column preceded by a gentle circular movement with the sampling ladle. Surveyors stood on the pond bank without entering the water to avoid possible contamination from their boots or from stirring up sediment. The $2 \mathrm{~L}$ water sample was 
homogenized by gently shaking the bag to ensure the eDNA was evenly mixed throughout the sample, and the whole $2 \mathrm{~L}$ water sample was then filtered directly in the field through a VigiDNA $0.45 \mu \mathrm{m}$ filter (SPYGEN, Le Bourget du Lac, France) using a sterile $100 \mathrm{~mL}$ syringe. The filter was filled with $80 \mathrm{~mL}$ of a CL1 conservative buffer (SPYGEN) and stored at room temperature before DNA extraction.

\subsection{Sediment Sampling}

At each of the six sampling sessions, sediment (approximately $10 \mathrm{~mL}$ ) was collected from 20 locations evenly distributed around Balaour pond. Each sediment sample was collected approximately $0.5 \mathrm{~m}$ from the shoreline using a sterile syringe $(20 \mathrm{~mL})$ pushed into the top $5 \mathrm{~cm}$ of sediment. The 20 samples were placed into a shared sterile bag, mixed together, and then stored in a sterile wide-neck barrel (1 L).

\subsection{Ranavirus Detection in Frogs, Tadpoles and Insects}

From the adult frogs, a small piece $\left(2 \mathrm{~mm}^{3}\right)$ of tissue was collected: Liver tissue from dead specimens (which were dissected) and toe tissue from live specimens. For small tadpoles, the total tadpole was used (e.g., individuals $<10 \mathrm{~mm}$, Gosner stage 25). For larger tadpoles (Gosner stages 30-45), individuals were dissected, and a total tissue volume of about $2 \mathrm{~mm}^{3}$ was collected, mostly composed of the liver and heart. For both aquatic and terrestrial insects, specimens were grouped per date of sampling and crushed together in $5 \mathrm{~mL}$ of $95 \%$ ethanol. A subsample of $1.5 \mathrm{~mL}$ was collected for DNA analysis.

The DNA was extracted with a REDExtract-N-Amp Plant Kit (Sigma-Aldrich-Merck, Darmstadt, Germany) by incubating a piece of tissue or the bulk of insects in $50 \mu \mathrm{L}$ of extraction solution at $95^{\circ} \mathrm{C}$ for $20 \mathrm{~min}$ after ethanol evaporation $\left(56^{\circ} \mathrm{C}\right.$ for $\left.30 \mathrm{~min}\right)$. An equal volume of dilution solution was added to the extract to neutralize inhibitory substances before a polymerase chain reaction (PCR).

The Taqman real-time quantitative PCRs were performed following the protocol described in detail in [13], using primers and probes designed by Leung et al. (2017) [32]. All assays were performed in triplicate. Ranavirus DNA, provided in several densities by Stephen Price (Zoological Society, London, UK), was used to calibrate the standard curve.

A sample was considered positive if the amplification curves were similar to those in positive controls (i.e., shape, cycle threshold, values, and $>0.1$ genomic equivalent), and at least two replicates gave positive amplification. If only one well resulted in a positive signal, the sample was rerun and was considered positive if at least two wells gave a positive amplification signal. The results were expressed in terms of genomic equivalent (GE) and prevalence (number of positive samples/total number of samples).

\subsection{Ranavirus Detection in Sediment}

The sediment samples were weighed, and a similar weight of a saturated phosphate buffer $\left(\mathrm{Na}_{2} \mathrm{HPO}_{4} ; 0.12 \mathrm{~m} ; \mathrm{pH} \approx 8\right)$ was added, as described in [33]. The DNA extraction was performed using a commercial kit for soil DNA (NucleoSpin ${ }^{\circledR}$ Soil; Macherey-Nagel, Düren, Germany), following the manufacturer's instructions. The PCR amplifications were performed following the protocol previously described for amphibian tissue and insects.

\subsection{Ranavirus Detection in Water}

For the water samples, DNA extraction was performed following the protocol described in [34] in a dedicated room for water DNA extraction equipped with positive air pressure, UV treatment, and frequent air renewal. Before entering this extraction room, personnel used a connecting zone to change into full protective clothing, comprising a disposable body suit with hood, mask, laboratory shoes, overshoes, and gloves. All workbenches were decontaminated with commercial bleach, diluted to achieve a $0.5 \%$ sodium hypochlorite solution, before and after each manipulation. For DNA extraction, each filtration capsule, containing the CL1 buffer, was agitated for 15 min on an S50 shaker 
(cat Ingenieurbüro ${ }^{\mathrm{TM}}$ ) at $800 \mathrm{rpm}$, and then the buffer was emptied into a $50 \mathrm{~mL}$ tube before being centrifuged for $15 \mathrm{~min}$ at $15,000 \times \mathrm{g}$. The supernatant was removed with a sterile pipette, leaving $15 \mathrm{~mL}$ of liquid at the bottom of the tube. Subsequently, $33 \mathrm{~mL}$ of ethanol and $1.5 \mathrm{~mL}$ of $3 \mathrm{M}$ sodium acetate were added to each $50 \mathrm{~mL}$ tube and stored for at least one night at $-20^{\circ} \mathrm{C}$. The tubes were centrifuged at $15,000 \times g$ for $15 \mathrm{~min}$ at $6{ }^{\circ} \mathrm{C}$, and the supernatants were discarded. After this step, $720 \mu \mathrm{L}$ of an ATL buffer from the DNeasy Blood \& Tissue Extraction Kit (Qiagen, Hilden, Germany) was added. The tubes were then vortexed, and the supernatants were transferred to $2 \mathrm{~mL}$ tubes containing $20 \mu \mathrm{L}$ of Proteinase K. The tubes were then incubated at $56{ }^{\circ} \mathrm{C}$ for two hours. Subsequently, DNA extraction was performed using NucleoSpin $囚 S o i l$ (MACHEREY-NAGEL GmbH \& Co., Düren, Germany) starting from step 6 and following the manufacturer's instructions. The elution was performed by adding $100 \mu \mathrm{L}$ of a SE buffer twice. After DNA extraction, the samples were tested for inhibition using real-time amplification following the protocol described in Biggs et al. (2015) [31], which involved adding a synthetic DNA sequence to each sample and then trying to amplify it. None of the samples were found to be inhibited. The samples were amplified using primers and probes designed by Leung et al. (2017) [32]. The qPCR was carried out in 12 replicates on a final volume of $25 \mu \mathrm{L}$, using $3 \mu \mathrm{L}$ of template DNA, 12.5 $\mu$ L of TaqMan Environmental Master Mix 2.0 (Life Technologies, Carlsbad, CA, USA), $6.5 \mu \mathrm{L}$ of ddH2O, $1 \mu \mathrm{L}$ of forward primer and reverse primer, and $1 \mu \mathrm{L}$ of probe (MCP_probe) using thermal cycling at $50^{\circ} \mathrm{C}$ for $5 \mathrm{~min}$ and $95^{\circ} \mathrm{C}$ for $10 \mathrm{~min}$, followed by 50 cycles at $95^{\circ} \mathrm{C}$ for $30 \mathrm{~s}$ and $60^{\circ} \mathrm{C}$ for $1 \mathrm{~min}$. To detect potential contamination, qPCR negative controls and DNA extraction controls (with 12 replicates) were amplified in parallel. Standard curve calculations were based on three standards $\left(4.5 \times 10^{7}, 4.5 \times 10^{4}\right.$, and $4.5 \times 10^{1}$ target copies per $\left.3 \mu \mathrm{L}\right)$ made from a plasmid containing the viral MCP target. Samples were run on a BIO-RAD CFX96 Touch real-time PCR detection system in a room dedicated to amplified DNA analysis with negative air pressure and physically separated from the DNA extraction room.

The results were expressed in terms of the number of positive replicates/total number of replicates per sample and the mean number of DNA copies (using the number of copies per Rv+ replicates) per sample.

\subsection{Ranavirus Identification}

Viral DNA was obtained from 1 dead adult, 3 live adults, 5 dead tadpoles, and 5 live tadpoles. These 14 samples were sequenced following the Mao et al. (1999) PCR method [35], using the BigDye Terminator Cycle Sequencing kit (PE Biosystems, Thermo Fisher Scientific, Bleiswijk, Netherlands) on an ABI Prism 3100 (Applied Biosystems, Foster City, CA, USA). The electropherogram was exported and converted to Kodon (Applied Maths, Sint-Martens-Latem, Belgium), and, using the BLAST program (default settings), the sequences were compared to Ranavirus sequences previously identified in this region [15].

\section{Results}

\subsection{Field Observations}

At altitudes above $2000 \mathrm{~m}$, the common frog breeds as soon as a small open body of water is available. The breeding population in Balaour pond has long been observed, but the population size has not been precisely estimated. The number of egg-masses is regularly around several hundred (M.-F. Lecchia, pers.comm.).

At Sampling Session 1 (10-11 June 2016), the breeding season had started, and about 200 egg-masses were counted. The embryos were at stages 9-11. Sixteen adults were observed in the water. One dead frog was observed at the bottom of the pond. At Session 2 (23-24 June), the tadpoles (stages 24 and 25) formed large aggregates on the remains of the spawn (jelly) along the pond shore. Fewer than 10 adults were observed in the water. At Session 3 (8 July), the tadpoles (stage 30) were grouped along the pond shore where the water temperature was highest. Five adults were observed in the water. At Session 4 
(27 July), the tadpoles (stages 35-39) were grouped along the pond shore. Dead tadpoles (about 250 counted) were observed on the bottom of the pond. Several individuals were observed with atypical behaviour, such as slow movements when stimulated, lateral swimming, or lying on their back on the pond bottom (about 50 counted). Most of the dead tadpoles were eaten by their congeners (Figure 1). Only two adults were observed in the water. At Session 5 (15-16 August), the tadpoles (stages 39-41) were more widespread in the pond, i.e., observed swimming beyond the $2 \mathrm{~m}$ strip near the shoreline. While we did not estimate the (relative) density at each session, the number of live tadpoles observed at Session 5 was clearly lower than at Session 4. No dead tadpoles were observed, nor tadpoles with the previously described atypical behaviour. Only two adults were observed in the pond. At Session 6 (19 September), most of the tadpoles had metamorphosed or were very close to metamorphosis (stages 43-45) and were widespread along the pond shore, both in the water and on land. No dead tadpoles or froglets were observed. Eight adults were observed in the pond.

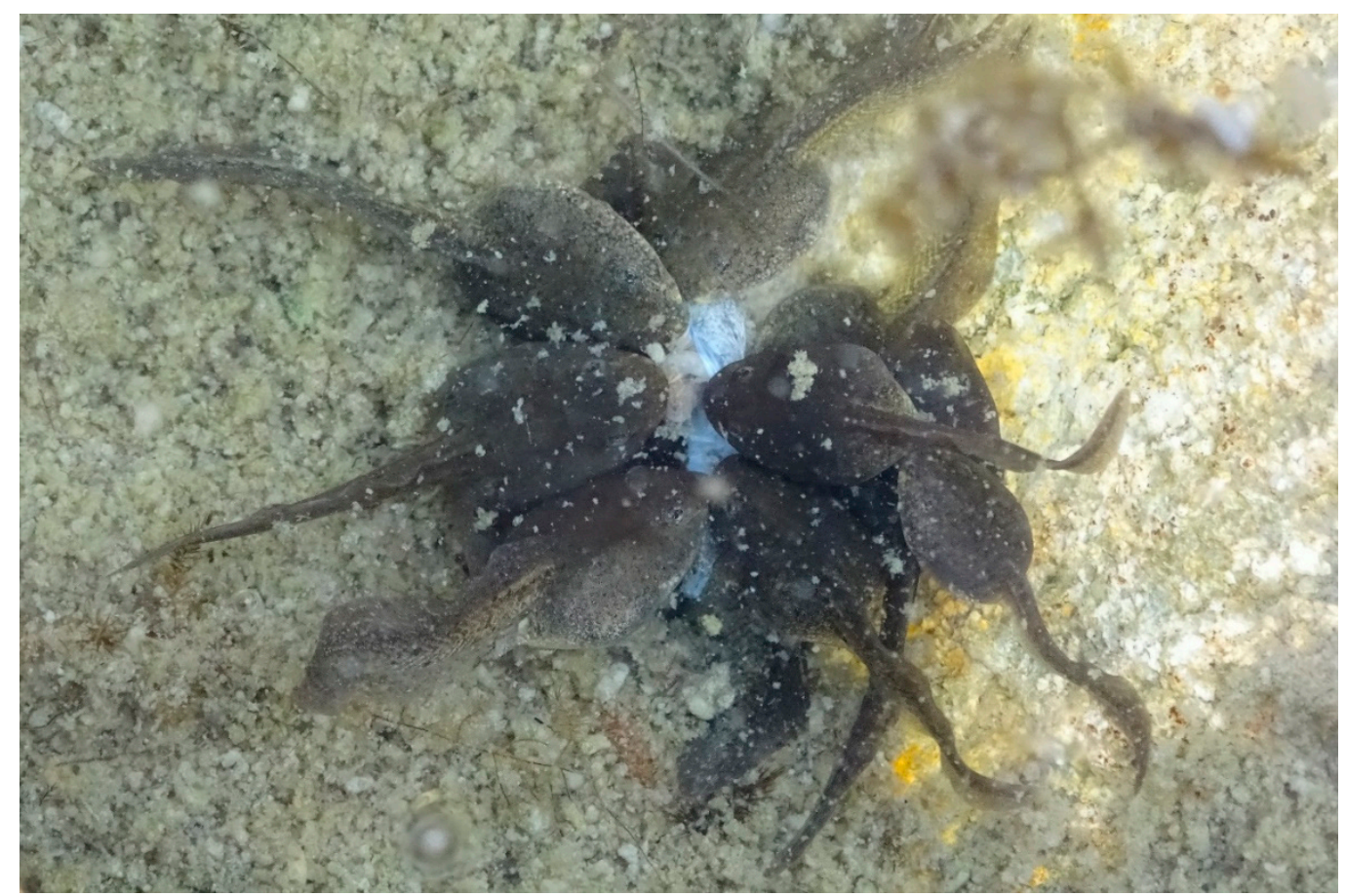

Figure 1. Common frog Rana temporaria tadpoles feeding on their dead congeners (photo L. Miaud).

Terrestrial insects (Diptera, Chironomids, Hymenoptera, Rhopalocera, and ants) and aquatic insects (Diptera, Heteroptera, and Odonata) were present around and in Balaour pond from June to September.

The two data loggers allowed the water temperature to be recorded at the surface and at a depth of $30 \mathrm{~cm}$ (Figure 2). The temperature increased from about $7^{\circ} \mathrm{C}$ in mid-June to $14^{\circ} \mathrm{C}$ at the beginning of July. The mean temperature during the July-August sampling period was $14^{\circ} \mathrm{C} \pm 4.3$, with a maximum of $20.5^{\circ} \mathrm{C}$ (at the surface) and $20^{\circ} \mathrm{C}$ (at a depth of $30 \mathrm{~cm}$ ) in July. In September, the temperature decreased to about $7^{\circ} \mathrm{C}$. 


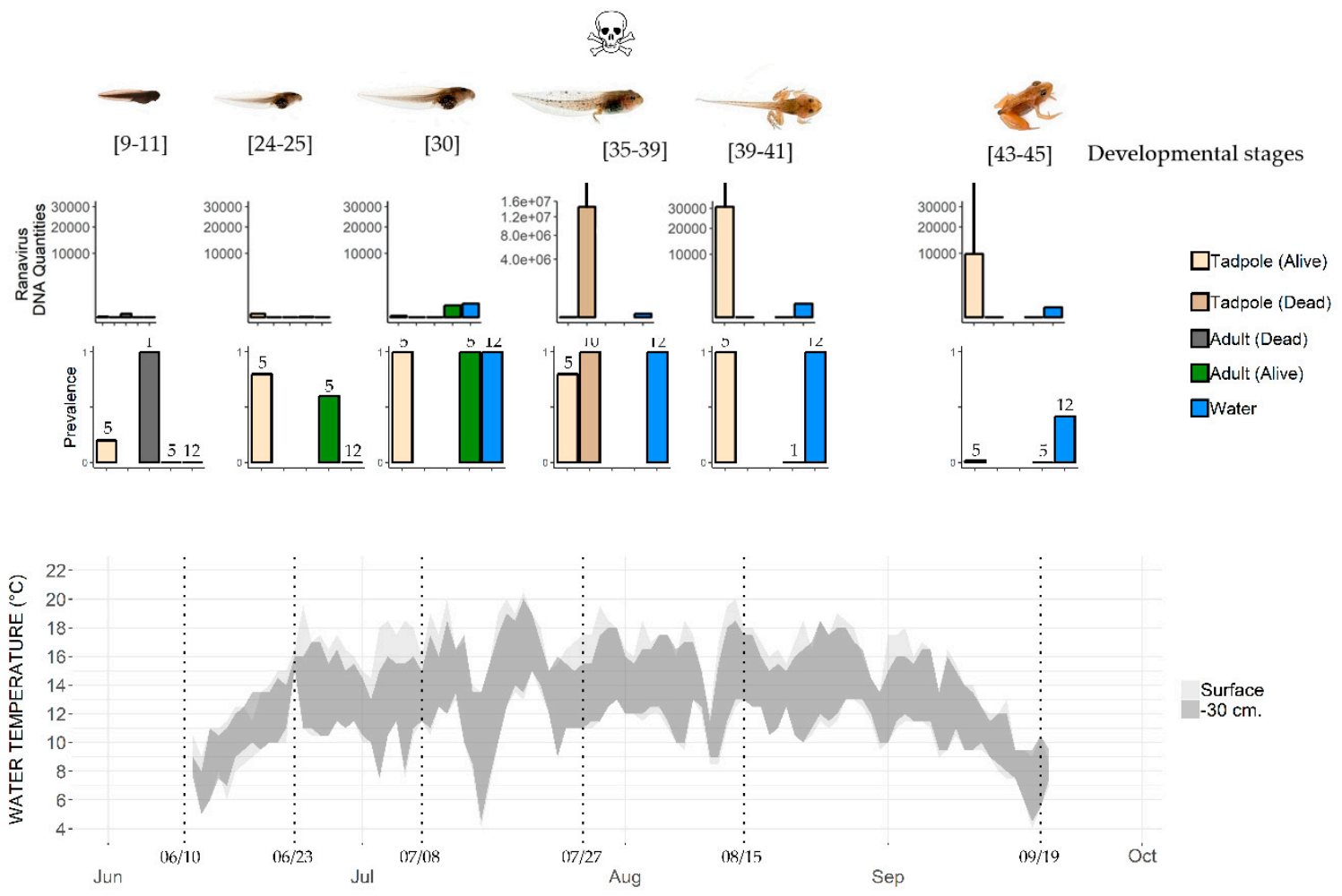

STUDY PERIOD

Figure 2. Change in water temperature and Ranavirus prevalence and load in a pond where the mass mortality of common frog tadpoles was observed. Water temperature was recorded at the surface and $30 \mathrm{~cm}$ below the surface. Top row of histograms: Ranavirus DNA quantities in common frogs (adults and tadpoles) and water samples (log scales, mean value, and SD). Bottom row of histograms: Prevalence (number of Ranavirus positive specimens/total number of sampled specimens, with sample size indicated above the bars). Developmental stages are based on Gosner stages; mortality was observed only on July 27.

\subsection{Ranavirus Detection in Organisms}

Ranavirus was detected in several compartments of the studied ecosystem (Supplementary Materials S1 and Figure 2) during the common frog activity period (June-September).

At Sampling Session 1 (10-11 June), the adult frogs present in the pond tested negative for Ranavirus (hereafter Rv-). The dead frog found on the pond bottom tested positive for Ranavirus (hereafter $\mathrm{Rv}+$ ) with a genomic equivalent (GE) load of $2.83 \times 10^{1}$ (Supplementary Materials S1 and Figure 2). At Session 2, 12 days later (23-24 June), three out of five adults were Rv+, with a mean GE of $0.43 \pm .1 .45(n=3)$. Adults caught in the water continued to be $\mathrm{Rv}+$ (four out of five testing positive) at Session 3 (8 July), with the highest mean GE ( $345 \pm 14.5, n=4$, Figure 2). No adults were sampled at Session 4 (27 July). The individual caught at Session 5 (15-16 August) and the five caught at Session 6 (19 September) were all Rv- (Figure 2). Most of the frogs that reproduce in Balaour pond leave the water after spawning to reach their surrounding terrestrial summer habitats. We did not catch adult frogs on land, so we do not know the infection status of these adults.

One recently hatched tadpole, i.e., hatched for less than one week in the prevailing environmental conditions at this altitude (water temperature about $6{ }^{\circ} \mathrm{C}$, Figure 2 and [29]), of the five tested was $\mathrm{Rv}+$ (Table 2). Thereafter, live tadpoles were Rv+ until metamorphosis (Session 6; 19 September). The prevalence of Ranavirus increased with time, reaching 100\% ( $n=5 / 5)$ at Session 5 (15-16 August), and then dropped to 20\% $(n=1 / 5)$ at Session 6 (19 September) (Figure 2). The variation in mean GE across the tadpole developmental period shows a rather low viral load until Session 4 (27 July) in live 
tadpoles, while the load in dead tadpoles was higher by an order of magnitude of $7\left(10^{7}\right)$. After this date, the GE values in live tadpoles stayed high $\left(10^{4}\right)$.

None of the terrestrial and aquatic insects collected from June to September tested positive for Ranavirus.

\subsection{Ranavirus Detection in Water}

Water samples from the first two sampling sessions were Rv- (Figure 2). From Session 3 (8 July) to Session 5 (15-16 August), the 12 qPCR replicates performed for each water sample were Rv+. Ranavirus was still detected at Session 6 (19 September), though it had the lowest detectability (5/12 replicates). The number of DNA copies (Figure 2) reached its maximum on 27 July (by an order of magnitude of 2), when the dead tadpoles were also observed with a high GE load. However, the GE values in infected live tadpoles and the number of DNA Ranavirus copies in water were not significantly correlated (Spearman rank correlation $R=0.25, p>0.05$ ).

\subsection{Ranavirus in Sediment}

All the qPCR replicates were negative for the samples collected at Sessions 1, 2, 4, and 6. At Sessions 3 and 5, 1 qPCR of the three was positive for both samples; these two samples were rerun. Only one positive replicate was observed again, so the two sediment samples were also considered negative.

\subsection{Ranavirus Identification}

The sequences obtained from the DNA extracted from dead tadpoles $(n=5)$, live tadpoles $(n=5)$, dead adults $(n=1)$, and live adults $(n=3)$ were $100 \%$ identical to the CMTV (GenBank accession number JQ231222) isolated from a common midwife toad (Alytes obstetricans; [12]) and an alpine newt (Ichthyosaura alpestris) in Spain [36]. This Ranavirus has been identified as the etiologic agent of the mass mortality of the common frogs observed in the region [13].

\section{Discussion}

\subsection{Seasonal Dynamics of Ranavirus Epidemics in a Common Frog Population}

The common frogs (tadpoles and adults, dead and alive) testing positive for Ranavirus (CMTV, [12]) in Balaour pond in 2016 confirm the widespread distribution of this pathogen in the south-eastern Alps [13].

At the first sampling session (10 June), egg-masses had been deposited in the pond, but only 16 adults were observed in the water, and they did not exhibit breeding behavior. Spawning in the common frog is synchronous and short in duration [37]. On this date, one dead adult was observed in the water. This specimen was $\mathrm{Rv}+$. Of the live adults, 5 specimens were $\mathrm{Rv}-$, while 1 out of 5 live tadpoles was $\mathrm{Rv}+$. Of the few adults that remained in the pond until July, some were $\mathrm{Rv}+$, but no further adult mortality was observed in the pond. In contrast, tadpoles suffered mass mortality at the end of July, when they reached developmental stages 35-39. Ranavirus was not detected in the sampled insects (aquatic or terrestrial), nor in the sediment collected during the summer activity period.

Sampling different life stages of organisms, as well as biotic and abiotic components, is necessary to provide a comprehensive view of Ranavirus dynamics (e.g., [38]). The observed dynamics in Balaour pond raise several questions: Ranavirus (including CMTV) is often highly pathogenic, and adult mass mortalities in common frog populations have been described in this region [13]. Yet adult mass mortality was not observed in Balaour pond in 2016. The breeding population is estimated to consist of at least 400 breeding adults (based on the observation of approximately 200 egg-masses in the pond and assuming an unbiased sex ratio [39]). Frog mass mortality is easily detectable in these small alpine ponds, so it is unlikely that an adult die-off went undetected. While frog aggregation during breeding can potentially foster pathogen transmission $[40,41]$, the small fraction of adults that remained in the water after breeding was not infected at the beginning of the activity season. We have no data on 
the infection status of adults coming to breed or leaving the water after breeding, and the source and timing of the Ranavirus introduction remain unknown. It is unlikely that Ranavirus persists in the pond water from one year to the next [42], so it may be that sub-lethally infected adults (hibernating in water or on land) expose hatchlings to Ranavirus each year. Other reservoir species may also contribute to seasonal epidemics [43]; Ranavirus has been detected in fish in neighboring lakes [13]. However, the studied pond is free of fish, and the other communities we tested (aquatic and terrestrial insects) were Rv-. The characteristics of Ranavirus persistence from year to year in this pond remain to be studied.

In contrast to adults, tadpoles did suffer mass mortality. Rapid and synchronous mass mortality of tadpoles in frog populations is well known [38]. The sudden introduction of a virus can be the cause of such a die-off, but this does not seem to be the case in Balaour pond, as Ranavirus was detected from the very beginning of the activity season. The existence of a window of host susceptibility mediated by environmental conditions (e.g., temperature) may contribute to this pattern (e.g., [38]). Ranavirus epidemics often occur during late spring or summer and can begin and end within weeks [38,44-47]. Infected tadpoles in Balaour pond were observed throughout the activity season (from June to September), i.e., from early developmental to pre-metamorphosis stages, while tadpoles died in mass only at the end of July, at stages 35-39 (Figure 2). Hall et al. (2018) [38] observed that Ranavirus prevalence reached high levels $(>50 \%)$ in wood frog tadpoles up to six weeks before mass mortality. High prevalence was also observed in the common frog population one month before the mass mortality in our study. In the wood frog [38], mortality occurred when tadpoles reached developmental stages (hind limb formation) that coincide with higher water temperatures $\left(>15^{\circ} \mathrm{C}\right)$. Several studies indicate that the pathogenicity of Ranavirus depends on the individual's developmental stage, with the most susceptible stage varying between species $[10,11,43,44]$. In our study, the tadpole die-off was found to coincide with the highest virus load in tadpole tissue (Figure 2, [48,49]). The accumulation of infectious dead tadpoles may also facilitate transmission (Figure 1, [50-52]). Water temperature, independent of developmental stage, has been shown to increase virus pathogenicity [53]. Common frog tadpoles suffer greater mortality at $20^{\circ} \mathrm{C}$ than at $15^{\circ} \mathrm{C}$, whether exposed to Ranavirus (FV3) or not [54]. The mass mortality of tadpoles observed in Balaour pond corresponded with the highest temperature recorded during the sampling period (Figure $2,20^{\circ} \mathrm{C}$ at the surface). However, no mortality was observed at the beginning of July or the end of August, when similar high temperatures were recorded. The respective and interacting roles of water temperature and tadpole developmental stage on Ranavirus pathogenicity remain to be studied in this common frog population.

\subsection{Designing Pathogen Surveys Using eDNA and Occupancy Models}

Diagnosing Ranavirus infection in amphibians requires collecting samples from either live individuals (e.g., a piece clipped from the tail or toe or skin swabs [55-57]) or dead individuals (e.g., a sample from the liver) [55]). However, Ranavirus can also resist adverse conditions (e.g., the drying out or freezing of a host carcass) and can then be shed into the water from infected individuals [58,59]. While viruses are rapidly degraded by microbes and zooplankton predation in water [42], they can remain detectable for at least seven days [60]. Water sampling and eDNA testing can thus indicate the presence of the pathogen; Hall et al. (2016) demonstrated that in ponds where wood frog tadpoles were $\mathrm{Rv}+$, collected water samples also revealed the presence of Ranavirus DNA [24]. Other pathogens have also been detected using water samples-several metazoan parasites [26,61,62], chytrid fungus $[21-25,27,63,64]$, and the Oomycota fungus Aphanomyces astaci, the causative agent of crayfish plague [28] — demonstrating the usefulness of eDNA for detecting pathogen infections in wildlife. 
Table 2. Water sampling for Chytris and Ranavirus detection.

\begin{tabular}{|c|c|c|c|c|c|c|}
\hline Pathogen & $\begin{array}{c}\text { Filter Mesh } \\
\text { Water Collection }\end{array}$ & $\begin{array}{c}\text { Volume of } \\
\text { Water Sample }\end{array}$ & Field Sampling & Date & $\begin{array}{l}\text { Occupancy } \\
\text { Design }\end{array}$ & Reference \\
\hline Chytrid & $\begin{array}{l}0.45 \mu \mathrm{m} \\
\text { Peristaltic pump }\end{array}$ & $\begin{array}{l}0.05 \text { to } 2.3 \mathrm{~L} \text { per site } \\
\text { (filter clogged) }\end{array}$ & $\begin{array}{c}\text { In shallow water ( } 0.1 \text { to } 0.75 \mathrm{~m} \text { deep) in known or likely } \\
\text { amphibian habitats. } \\
3 \text { locations per site, } 4 \text { sites }\end{array}$ & 1 date & no & [21] \\
\hline Chytrid & $\begin{array}{l}0.45 \mu \mathrm{m} \\
50 \mathrm{~mL} \text { syringe }\end{array}$ & $\begin{array}{l}<1 \text { L per site } \\
\text { (filter clogged) }\end{array}$ & $\begin{array}{l}\text { Within } 10 \mathrm{~cm} \text { of the edge } \\
1 \text { location per site, } 42 \text { sites }\end{array}$ & 1 date & no & [22] \\
\hline Chytrid & $\begin{array}{l}0.22 \mu \mathrm{m} \\
60 \mathrm{~mL} \text { syringe }\end{array}$ & $600 \mathrm{~mL}$ per site & $\begin{array}{c}\text { Samples spaced evenly along the entire site circumference, but taken } \\
\text { only from areas } \\
\text { where frogs or tadpoles were present } \\
30 \text { samples of } 20 \mathrm{~mL} \text { combined, } 20 \text { sites }\end{array}$ & 4 dates & No, yes * & {$[23,63]$} \\
\hline Chytrid & $\begin{array}{l}1.2 \mu \mathrm{m} \\
\text { Hand pump }\end{array}$ & 500 to $1500 \mathrm{~mL}$ per site & $\begin{array}{l}\text { Every } 40 \mathrm{~m} \text { along the shoreline. } \\
5 \text { samples of } 50 \mathrm{~mL} \text { combined, } 13 \text { sites }\end{array}$ & 1 date & no & [26] \\
\hline Chytrid & $\begin{array}{l}0.22 \mu \mathrm{m} \\
60 \mathrm{~mL} \text { syringe }\end{array}$ & $20 \mathrm{~mL}$ to $2.4 \mathrm{~L}$ per site & $\begin{array}{l}\text { In shallow water ( } 5 \text { and } 20 \mathrm{~cm} \text { below the water surface) } \\
3 \text { spatial replicates per site, } 41 \text { sites }\end{array}$ & 1 date & yes & [64] \\
\hline Ranavirus & $\begin{array}{l}0.2 \mu \mathrm{m} \\
\text { Disposable paper cup }\end{array}$ & $\begin{array}{l}750 \mathrm{~mL} \\
250 \mathrm{~mL} \times 3 \text { per site }\end{array}$ & $\begin{array}{c}\text { At } 3 \text { distinct locations (north, east and west) along the shore and } \\
\text { surface (ca. } 10 \mathrm{~cm} \text { deep) } \\
3 \text { spatial replicates per site, } 20 \text { sites }\end{array}$ & 1 date & yes & [24] \\
\hline Ranavirus & $\begin{array}{c}0.2 \mu \mathrm{m} \\
\text { Disposable paper cup }\end{array}$ & $\begin{array}{l}750 \mathrm{~mL} \\
250 \mathrm{~mL} \times 3 \text { per site }\end{array}$ & $\begin{array}{l}\text { As above } \\
8 \text { sites }\end{array}$ & 16 dates & no & [27] \\
\hline $\begin{array}{l}\text { Chytrids } \\
\text { Ranavirus }\end{array}$ & $\begin{array}{l}0.2 \mu \mathrm{m} \\
\text { Hand pump }\end{array}$ & $\begin{array}{l}0.6-1 \mathrm{~L} \\
150-250 \mathrm{~mL} \times 4 \text { per site }\end{array}$ & $\begin{array}{l}4 \text { locations approximately equidistant around the site (within } 2 \mathrm{~m} \text { of } \\
\text { the edge and } 20-40 \mathrm{~cm} \text { below the surface), } 4 \text { spatial replicates per } \\
\text { site; } 21 \text { sites }\end{array}$ & 3 dates & yes & [65] \\
\hline Ranavirus & $\begin{array}{l}\quad 0.45 \mu \mathrm{m} \\
\text { Sterile water-sample dipper }\end{array}$ & $\begin{aligned} & 2 \mathrm{~L} \\
100 \mathrm{~mL} \times 20 \text { combined } & \end{aligned}$ & $\begin{array}{l}20 \text { locations equidistant around the site (within } 0.5 \mathrm{~m} \text { of the edge } \\
\text { and } 10 \mathrm{~cm} \text { below the surface), } 1 \text { site }\end{array}$ & 6 dates & no & This study \\
\hline
\end{tabular}

* the same data set was used in the two studies. 
Table 2 summarizes different methods used to collect water for pathogen detection (Chytrids and Ranavirus). The most usual method is to collect water samples that are then filtered in the field. The filters are then stored until DNA extraction and amplification in the laboratory. The sampling design varies, e.g., discrete samples may be filtered separately or combined before filtering (Table 2). The location of the water sampling also differs, from rather exhaustive sampling (e.g., at approximately equidistant locations around the site) to solely where the presence of the pathogen would be expected (e.g., locations where frogs or tadpoles have been present). Water collection and filtering procedures are simple and have been used by non-experts in a citizen science program [65]. Clearly, the detection of a pathogen in water samples depends on its density (DNA quantities) and distribution (e.g., continuous or patchy) in the studied site. Several estimates concerning sampling effort are available; Julian et al. (2019) evaluated that as few as five water samples (Table 2) taken in June or July can detect both Bd and Ranavirus with 95\% confidence [65]. In another study, every pond with Ranavirus-infected tadpoles tested positive with just three $250 \mathrm{~mL}$ water samples (Table 2, [27]). In our study, Ranavirus detection from water samples was effective in four out of six sessions, i.e., $66.6 \%$ detectability. In contrast, mass mortality was observed on only one date, i.e., $16.6 \%$ detectability. When live tadpoles were collected and molecular diagnostics performed, the presence of the pathogen was detected throughout the six sampling dates ( $100 \%$ detectability). Increasing the number of water samples will increase the cost of the molecular diagnostics, but pooling the samples before filtration allows a good sampling coverage of the study area at a reasonable cost. When the distribution of the pathogen (or the potential hosts) is known, we recommend to perform a pilot study to optimize the number (or volume) of water samples. Without preliminary knowledge, the screening of the site can be based on samples spaced evenly along the entire site circumference, then combined in one water samples which is then filtered to collect DNA.

Nonetheless, most pathogen detection tests are imperfect, resulting in false negatives when a pathogen is present but not detected. False negatives can occur when specimens or water samples are collected in the field, from organs in infected hosts (histological diagnostics) or in PCR replicates (molecular diagnostics). To address this, multi-scale occupancy models [66] can be used to develop a species distribution model to estimate the proportion of sites where a species or a pathogen occurs [67], even when detection is imperfect. This statistical framework is particularly suitable for eDNA analyses in which replicates (and thus detection probability) are present at the different steps of the method [68]; for example, it has been recommended in disease ecology [69]. Table 2 provides some studies that used eDNA to detect Bd or Ranavirus as well as occupancy models to estimate pathogen prevalence. Naïve prevalence (i.e., estimated prevalence without taking into account imperfect detection) can lead to the underestimation of Bd prevalence in ponds [23]; estimating correct prevalence requires taking multiple samples per site (Table 2). Replicates to evaluate detection probabilities can be temporal (i.e., sampling the same site at least three occasions) or spatial (i.e., sampling in at least three locations in the site) [66].

\section{Conclusions}

Inferring the health status of common frogs or ecologically similar amphibian species based only on the observation of mass mortality events in breeding sites runs the risk of missing potential infections. A better strategy is to sample amphibian tissue (adults and/or tadpoles) during, for example, the tadpole developmental phase and then perform molecular diagnostics. As this requires invasive techniques, administrative authorizations for protected species and/or protected areas and specific materials to collect and store the samples are needed. In some cases, catching frogs and tadpoles can be challenging, and tissue sampling requires a certain level of technical competence (and, sometimes, certified training). In light of these challenges, our results confirm previous findings that eDNA can be an effective alternative, since the temporal window for detecting the pathogen is rather large, collecting water samples is simple and can be performed by most field technicians, and, moreover, no specimen has to be caught, manipulated, or sacrificed. Moreover, applying a sampling design based on occupancy modelling (e.g., replicates allowing the evaluation of detection probability) provides prevalence estimates that are comparable between sites or years. As a biodiversity inventory method 
in marine and freshwater environments, eDNA has been extraordinarily successful; likewise, it holds clear potential for improving disease surveillance programs and increasing the performance of wildlife health status monitoring.

Supplementary Materials: Supplementary materials can be found at http:/www.mdpi.com/1999-4915/11/6/526/s1.

Author Contributions: C.M. conceived and designed the experiment. C.M. conducted the experiment in the field. V.A., A.V., M.P., and T.D. performed the pathogen detection analysis. C.M., A.V., and T.D. wrote the paper.

Funding: This work was funded in part by a research convention signed between Mercantour National Park and the French École Pratique des Hautes Études (EPHE).

Acknowledgments: We would like to thank Coralie Barbier, Léo Miaud, Benjamin Viel, and the technicians of the Mercantour National Park for their help in the field, Marie-Laure Leccia for her support in studying the health status of the park's amphibian population, and Stephen Price for the MCP standards and help with the qPCR protocol. Discussions with A. Duffus, T. Garner, W. Leung, S. Price, and F. Pasmans on the design of the longitudinal study were greatly appreciated. Jules Chiffard and Antoine Miaud kindly created Figure 2. Authorisation to collect the tadpoles and to sample tissue from the adults was provided by Mercantour National Park (authorisation $n^{\circ}$ 2016-408, 12 May 2016) and the Alpes-de-Haute-Provence Regional Department of the Environment, Development and Housing (prefectural decree, 20 May 2016). Many thanks to Elise Bradbury (elisebrad@gmail.com) for the text review and editing. A first draft of this manuscript was highly improved by the reviewer's constructive comments.

Conflicts of Interest: The authors declare no conflict of interest.

\section{References}

1. Miaud, C.; Guillaume, O. Are amphibian good biological indicators? In Proceedings of the Abstract of the Fifth World Congress of Herpetology 2005, Stellenbosch, South Africa, 19-24 June 2005; p. 72.

2. Welsh, H.H.; Ollivier, L.M. Stream Amphibians as Indicators of Ecosystem Stress: A Case Study from California's Redwoods. Ecol. Appl. 1998, 8, 1118-1132. [CrossRef]

3. Temple, H.J.; Cox, N.A. European Red List of Amphibians; Office for Official Publications of the European Communities: Luxembourg, 2009.

4. Daszak, P.; Berger, L.; Cunningham, A.A.; Hyatt, A.D.; Green, D.E.; Speare, R. Emerging infectious diseases and amphibian population declines. Emerg. Infect. Dis 1999, 5, 735-748. [CrossRef] [PubMed]

5. $\quad$ Lips, K.R.; Brem, F.; Brenes, R.; Reeve, J.D.; Alford, R.A.; Voyles, J.; Carey, C.; Livo, L.; Pessier, A.P.; Collins, J.P. Emerging infectious disease and the loss of biodiversity in a Neotropical amphibian community. Proc. Natl. Acad. Sci. USA 2006, 103, 3165-3170. [CrossRef] [PubMed]

6. Rachowicz, L.J.; Knapp, R.A.; Morgan, J.A.T.; Stice, M.J.; Vredenburg, V.T.; Parker, J.M.; Briggs, C.J. Emerging infectious disease as a proximate cause of amphibian mass mortality. Ecology 2006, 87, 1671-1683. [CrossRef]

7. Scheele, B.C.; Pasmans, F.; Skerratt, L.F.; Berger, L.; Martel, A.; Beukema, W.; Acevedo, A.A.; Burrowes, P.A.; Carvalho, T.; Catenazzi, A.; et al. Amphibian fungal panzootic causes catastrophic and ongoing loss of biodiversity. Science 2019, 363, 1459-1463. [CrossRef] [PubMed]

8. Gray, M.J.; Chinchar, V.G. Ranaviruses: Lethal Pathogens of Ectothermic Vertebrates; Springer Science + Business Media: Berlin, Germany, 2015; ISBN 978-3-319-13755-1.

9. Chinchar, V.G. Ranaviruses (family Iridoviridae): Emerging cold-blooded killers-Brief review. Arch. Virol. 2002, 147, 447-470. [CrossRef] [PubMed]

10. Price, S.J.; Garner, T.W.J.; Nichols, R.A.; Balloux, F.; Ayres, C.; Mora-Cabello de Alba, A.; Bosch, J. Collapse of Amphibian Communities Due to an Introduced Ranavirus. Curr. Biol. 2014, 24, 2586-2591. [CrossRef]

11. Miller, D.; Gray, M.; Storfer, A. Ecopathology of Ranaviruses Infecting Amphibians. Viruses 2011, 3, $2351-2373$. [CrossRef]

12. Balseiro, A.; Dalton, K.P.; del Cerro, A.; Marquez, I.; Cunningham, A.A.; Parra, F.; Prieto, J.M.; Casais, R. Pathology, isolation and molecular characterisation of a ranavirus from the common midwife toad Alytes obstetricans on the Iberian Peninsula. Dis. Aquat. Organ. 2009, 84, 95-104. [CrossRef]

13. Miaud, C.; Pozet, F.; Gaudin, N.C.G.; Martel, A.; Pasmans, F.; Labrut, S. Ranavirus Causes Mass Die-Offs of Alpine Amphibians in the Southwestern Alps, France. J. Wildl. Dis. 2016, 52, 242-252. [CrossRef] 
14. Saucedo, B.; Hughes, J.; Spitzen-van der Sluijs, A.; Kruithof, N.; Schills, M.; Rijks, J.M.; Jacinto-Maldonado, M.; Suarez, N.; Haenen, O.L.M.; Voorbergen-Laarman, M.; et al. Ranavirus genotypes in the Netherlands and their potential association with virulence in water frogs (Pelophylax spp.). Emerg. Microbes Infect. 2018, 7, 56. [CrossRef] [PubMed]

15. Anonymous. Preventing emerging infectious diseases: A strategy for the 21st century. Overview of the updated CDC plan. MMWR Recomm. Rep. 1998, 47, 1-14.

16. Brunner, J.L.; Schock, D.M.; Davidson, E.W.; Collins, J.P. Intraspecific reservoirs: Complex life history and the persistence of a lethal ranavirus. Ecology 2004, 85, 560-566. [CrossRef]

17. Tibpromma, S.; Hyde, K.D.; Jeewon, R.; Maharachchikumbura, S.S.N.; Liu, J.-K.; Bhat, D.J.; Jones, E.B.G.; McKenzie, E.H.C.; Camporesi, E.; Bulgakov, T.S.; et al. Fungal diversity notes 491-602: Taxonomic and phylogenetic contributions to fungal taxa. Fungal Divers. 2017, 83, 1-261. [CrossRef]

18. Mokili, J.L.; Rohwer, F.; Dutilh, B.E. Metagenomics and future perspectives in virus discovery. Curr. Opin. Virol. 2012, 2, 63-77. [CrossRef] [PubMed]

19. Guy, R.A.; Payment, P.; Krull, U.J.; Horgen, P.A. Real-time PCR for quantification of Giardia and Cryptosporidium in environmental water samples and sewage. Appl. Environ. Microbiol. 2003, 69, 5178-5185. [CrossRef] [PubMed]

20. Ganoza, C.A.; Matthias, M.A.; Collins-Richards, D.; Brouwer, K.C.; Cunningham, C.B.; Segura, E.R.; Gilman, R.H.; Gotuzzo, E.; Vinetz, J.M. Determining risk for severe leptospirosis by molecular analysis of environmental surface waters for pathogenic Leptospira. PLoS Med. 2006, 3, 1329-1340. [CrossRef]

21. Walker, S.F.; Salas, M.B.; Jenkins, D.; Garner, T.W.J.; Cunningham, A.A.; Hyatt, A.D.; Bosch, J.; Fisher, M.C. Environmental detection of Batrachochytrium dendrobatidis in a temperate climate. Dis. Aquat. Organ. 2007, 77, 105-112. [CrossRef] [PubMed]

22. Kirshtein, J.D.; Anderson, C.W.; Wood, J.S.; Longcore, J.E.; Voytek, M.A. Quantitative PCR detection of batrachochytrium dendrobatidis DNA from sediments and water. Dis. Aquat. Organ. 2007, 77, 11-15. [CrossRef]

23. Schmidt, B.R.; Kery, M.; Ursenbacher, S.; Hyman, O.J.; Collins, J.P. Site occupancy models in the analysis of environmental DNA presence/absence surveys: A case study of an emerging amphibian pathogen. Methods Ecol. Evol. 2013, 4, 646-653. [CrossRef]

24. Hall, E.M.; Crespi, E.J.; Goldberg, C.S.; Brunner, J.L. Evaluating environmental DNA-based quantification of ranavirus infection in wood frog populations. Mol. Ecol. Resour. 2016, 16, 423-433. [CrossRef] [PubMed]

25. Kamoroff, C.; Goldberg, C.S. Using environmental DNA for early detection of amphibian chytrid fungus Batrachochytrium dendrobatidis prior to a ranid die-off. Dis. Aquat. Organ. 2017, 127, 75-79. [CrossRef] [PubMed]

26. Sato, M.O.; Rafalimanantsoa, A.; Ramarokoto, C.; Rahetilahy, A.M.; Ravoniarimbinina, P.; Kawai, S.; Minamoto, T.; Sato, M.; Kirinoki, M.; Rasolofo, V.; et al. Usefulness of environmental DNA for detecting Schistosoma mansoni occurrence sites in Madagascar. Int. J. Infect. Dis. 2018, 76, 130-136. [CrossRef] [PubMed]

27. Mosher, B.A.; Huyvaert, K.P.; Bailey, L.L. Beyond the swab: Ecosystem sampling to understand the persistence of an amphibian pathogen. Oecologia 2018, 188, 319-330. [CrossRef] [PubMed]

28. Robinson, C.V.; Uren Webster, T.M.; Cable, J.; James, J.; Consuegra, S. Simultaneous detection of invasive signal crayfish, endangered white-clawed crayfish and the crayfish plague pathogen using environmental DNA. Biol. Conserv. 2018, 222, 241-252. [CrossRef]

29. Miaud, C.; Guyetant, R.; Elmberg, J. Variations in life-history traits in the common frog Rana temporaria (Amphibia: Anura): A literature review and new data from the French Alps. J. Zool. 1999, 249, 61-73. [CrossRef]

30. Gosner, K.L. A Simplified Table for Staging Anuran Embryos and Larvae with Notes on Identification. Herpetologica 1960, 16, 183-190.

31. Biggs, J.; Ewald, N.; Valentini, A.; Gaboriaud, C.; Dejean, T.; Griffiths, R.A.; Foster, J.; Wilkinson, J.W.; Arnell, A.; Brotherton, P.; et al. Using eDNA to develop a national citizen science-based monitoring programme for the great crested newt (Triturus cristatus). Biol. Conserv. 2015, 183, 19-28. [CrossRef]

32. Leung, W.T.M.; Thomas-Walters, L.; Garner, T.W.J.; Balloux, F.; Durrant, C.; Price, S.J. A quantitative-PCR based method to estimate ranavirus viral load following normalisation by reference to an ultraconserved vertebrate target. J. Virol. Methods 2017, 249, 147-155. [CrossRef] 
33. Taberlet, P.; Prud'homme, S.M.; Campione, E.; Roy, J.; Miquel, C.; Shehzad, W.; Gielly, L.; Rioux, D.; Choler, P.; Clement, J.-C.; et al. Soil sampling and isolation of extracellular DNA from large amount of starting material suitable for metabarcoding studies. Mol. Ecol. 2012, 21, 1816-1820. [CrossRef]

34. Pont, D.; Rocle, M.; Valentini, A.; Civade, R.; Jean, P.; Maire, A.; Roset, N.; Schabuss, M.; Zornig, H.; Dejean, T. Environmental DNA reveals quantitative patterns of fish biodiversity in large rivers despite its downstream transportation. Sci. Rep. 2018, 8, 10361. [CrossRef] [PubMed]

35. Mao, J.H.; Green, D.E.; Fellers, G.; Chinchar, V.G. Molecular characterization of iridoviruses isolated from sympatric amphibians and fish. Virus Res. 1999, 63, 45-52. [CrossRef]

36. Mavian, C.; López-Bueno, A.; Balseiro, A.; Casais, R.; Alcamí, A.; Alejo, A. The Genome Sequence of the Emerging Common Midwife Toad Virus Identifies an Evolutionary Intermediate within Ranaviruses. J. Virol. 2012, 86, 3617. [CrossRef] [PubMed]

37. Haapanen, A. Breeding of the Common Frog (rana-Temporaria L). Ann. Zool. Fenn. 1982, 19, 75-79.

38. Hall, E.M.; Goldberg, C.S.; Brunner, J.L.; Crespi, E.J. Seasonal dynamics and potential drivers of ranavirus epidemics in wood frog populations. Oecologia 2018, 188, 1253-1262. [CrossRef] [PubMed]

39. Elmberg, J. Long-Term Survival, Length of Breeding-Season, and Operational Sex-Ratio. Can. J. Zool.-Rev. Can. Zool. 1990, 68, 121-127. [CrossRef]

40. Cunningham, A.A.; Langton, T.E.S.; Bennett, P.M.; Lewin, J.F.; Drury, S.E.N.; Gough, R.E.; MacGregor, S.K. Pathological and microbiological findings from incidents of unusual mortality of the common frog (Rana temporaria). Philos. Trans. R. Soc. Lond. Ser. B Biol. Sci. 1996, 351, 1539-1557.

41. Price, S.J.; Garner, T.W.J.; Cunningham, A.A.; Langton, T.E.S.; Nichols, R.A. Reconstructing the emergence of a lethal infectious disease of wildlife supports a key role for spread through translocations by humans. Proc. R. Soc. B Biol. Sci. 2016, 283, 20160952. [CrossRef] [PubMed]

42. Johnson, A.F.; Brunner, J.L. Persistence of an amphibian ranavirus in aquatic communities. Dis. Aquat. Org. 2014, 111, 129-138. [CrossRef]

43. Duffus, A.L.J.; Pauli, B.D.; Wozney, K.; Brunetti, C.R.; Berrill, M. FROG VIRUS 3-LIKE INFECTIONS IN AQUATIC AMPHIBIAN COMMUNITIES. J. Wildl. Dis. 2008, 44, 109-120. [CrossRef]

44. Green, D.E.; Converse, K.A.; Schrader, A.K. Epizootiology of sixty-four amphibian morbidity and mortality events in the USA, 1996-2001. In Domestic Animal/Wildlife Interface: Issue for Disease Control, Conservation, Sustainable Food Production, and Emerging Diseases; Gibbs, E.P.J., Bokma, B.H., Eds.; New York Acad Sciences: New York, NY, USA, 2002; Volume 969, pp. 323-339. ISBN 978-1-57331-439-8.

45. Gray, M.J.; Miller, D.L.; Hoverman, J.T. Ecology and pathology of amphibian ranaviruses. Dis. Aquat. Org. 2009, 87, 243-266. [CrossRef] [PubMed]

46. Rosa, G.M.; Sabino-Pinto, J.; Laurentino, T.G.; Martel, A.; Pasmans, F.; Rebelo, R.; Griffiths, R.A.; Stoehr, A.C.; Marschang, R.E.; Price, S.J.; et al. Impact of asynchronous emergence of two lethal pathogens on amphibian assemblages. Sci. Rep. 2017, 7, 43260. [CrossRef] [PubMed]

47. Rijks, J.M.; Saucedo, B.; Spitzen-van der Sluijs, A.; Wilkie, G.S.; van Asten, A.J.A.M.; van den Broek, J.; Boonyarittichaikij, R.; Stege, M.; van der Sterren, F.; Martel, A.; et al. Investigation of Amphibian Mortality Events in Wildlife Reveals an On-Going Ranavirus Epidemic in the North of the Netherlands. PLoS ONE 2016, 11, e0157473. [CrossRef] [PubMed]

48. Kik, M.; Martel, A.; Spitzen-van der Sluijs, A.; Pasmans, F.; Wohlsein, P.; Grone, A.; Rijks, J.M. Ranavirus-associated mass mortality in wild amphibians, The Netherlands, 2010: A first report. Vet. J. 2011, 190, 284-286. [CrossRef] [PubMed]

49. Hoverman, J.T.; Gray, M.J.; Miller, D.L.; Haislip, N.A. Widespread Occurrence of Ranavirus in Pond-Breeding Amphibian Populations. EcoHealth 2012, 9, 36-48. [CrossRef] [PubMed]

50. Pearman, P.B.; Garner, T.W.J.; Straub, M.; Greber, U.F. Response of the Italian agile frog (Rana latastei) to a Ranavirus, frog virus 3: A model for viral emergence in naive populations. J. Wildl. Dis. 2004, 40, 660-669. [CrossRef] [PubMed]

51. Harp, E.M.; Petranka, J.W. Ranavirus in wood frogs (Rana sylvatica): Potential sources of transmission within and between ponds. J. Wildl. Dis. 2006, 42, 307-318. [CrossRef] [PubMed]

52. Torrence, S.M.; Green, D.E.; Benson, C.J.; Ip, H.S.; Smith, L.M.; McMurry, S.T. A New Ranavirus Isolated from Pseudacris clarkii Tadpoles in Playa Wetlands in the Southern High Plains, Texas. J. Aquat. Anim. Health 2010, 22, 65-72. [CrossRef] [PubMed] 
53. Echaubard, P.; Leduc, J.; Pauli, B.; Chinchar, V.G.; Robert, J.; Lesbarreres, D. Environmental dependency of amphibian-ranavirus genotypic interactions: Evolutionary perspectives on infectious diseases. Evol. Appl. 2014, 7, 723-733. [CrossRef]

54. Bayley, A.E.; Hill, B.J.; Feist, S.W. Susceptibility of the European common frog Rana temporaria to a panel of ranavirus isolates from fish and amphibian hosts. Dis. Aquat. Org. 2013, 103, 171-183. [CrossRef] [PubMed]

55. Greer, A.L.; Collins, J.P. Sensitivity of a diagnostic test for amphibian ranavinus varies with sampling protocol. J. Wildl. Dis. 2007, 43, 525-532. [CrossRef] [PubMed]

56. St-Ainour, V.; Lesbarreres, D. Genetic evidence of Ranavirus in toe clips: An alternative to lethal sampling methods. Conserv. Genet. 2007, 8, 1247-1250. [CrossRef]

57. Gray, M.J.; Miller, D.L.; Hoverman, J.T. Reliability of non-lethal surveillance methods for detecting ranavirus infection. Dis. Aquat. Org. 2012, 99, 1-6. [CrossRef] [PubMed]

58. Brunner, J.L.; Collins, J.P. Testing assumptions of the trade-off theory of the evolution of parasite virulence. Evol. Ecol. Res. 2009, 11, 1169-1188.

59. Robert, J.; George, E.; Andino, F.D.J.; Chen, G. Waterborne infectivity of the Ranavirus frog virus 3 in Xenopus laevis. Virology 2011, 417, 410-417. [CrossRef] [PubMed]

60. Grizzle, J.M.; Brunner, C.J. Review of largemouth bass virus. Fisheries 2003, 28, 10-14. [CrossRef]

61. Huver, J.R.; Koprivnikar, J.; Johnson, P.T.J.; Whyard, S. Development and application of an eDNA method to detect and quantify a pathogenic parasite in aquatic ecosystems. Ecol. Appl. 2015, 25, 991-1002. [CrossRef] [PubMed]

62. Rusch, J.C.; Hansen, H.; Strand, D.A.; Markussen, T.; Hytterod, S.; Vralstad, T. Catching the fish with the worm: A case study on eDNA detection of the monogenean parasite Gyrodactylus salaris and two of its hosts, Atlantic salmon (Salmo salar) and rainbow trout (Oncorhynchus mykiss). Parasit. Vect. 2018, 11, 333. [CrossRef]

63. Hyman, O.J.; Collins, J.P. Evaluation of a filtration-based method for detecting Batrachochytrium dendrobatidis in natural bodies of water. Dis. Aquat. Org. 2012, 97, 185-195. [CrossRef]

64. Chestnut, T.; Anderson, C.; Popa, R.; Blaustein, A.R.; Voytek, M.; Olson, D.H.; Kirshtein, J. Heterogeneous Occupancy and Density Estimates of the Pathogenic Fungus Batrachochytrium dendrobatidis in Waters of North America. PLoS ONE 2014, 9, e106790. [CrossRef]

65. Julian, J.; Glenney, G.; Rees, C. Evaluating observer bias and seasonal detection rates in amphibian pathogen eDNA collections by citizen scientists. Dis. Aquat. Organ. 2019, 134, 15-24. [CrossRef]

66. MacKenzie, D.I.; Nichols, J.D.; Lachman, G.B.; Droege, S.; Andrew Royle, J.; Langtimm, C.A. Estimating Site Occupancy Rates When Detection Probabilities Are Less Than One. Ecology 2002, 83, 2248-2255. [CrossRef]

67. Colvin, M.E.; Peterson, J.T.; Kent, M.L.; Schreck, C.B. Occupancy Modeling for Improved Accuracy and Understanding of Pathogen Prevalence and Dynamics. PloS ONE 2015, 10, e0116605. [CrossRef] [PubMed]

68. Yoccoz, N.G. The future of environmental DNA in ecology: NEWS AND VIEWS: OPINION. Mol. Ecol. 2012, 21, 2031-2038. [CrossRef] [PubMed]

69. McClintock, B.T.; Nichols, J.D.; Bailey, L.L.; MacKenzie, D.I.; Kendall, W.L.; Franklin, A.B. Seeking a second opinion: Uncertainty in disease ecology: Uncertainty in disease ecology. Ecol. Lett. 2010, 13, 659-674. [CrossRef] [PubMed]

(C) 2019 by the authors. Licensee MDPI, Basel, Switzerland. This article is an open access article distributed under the terms and conditions of the Creative Commons Attribution (CC BY) license (http://creativecommons.org/licenses/by/4.0/). 